\title{
Profesyonel Futbol ve Voleybol Oyuncularının Beslenme Durumlarl, Beslenme Bilgi Düzeyleri, Kafein Alımları ve Vücut Kompozisyonları Arasındaki İlişkinin Değerlendirilmesi
}

\author{
Evaluation of the Relationship Between Nutritional Status, Nutritional Knowledge, \\ Caffeine Consumption and Body Composition of Professional Soccer and Volleyball
} Players

\author{
${ }^{1}$ Aysu AYHAN \\ ${ }^{1}$ Selen MÜFTÜOĞLU \\ ${ }^{1}$ Beril KÖSE
}

${ }^{1}$ Başkent Üniversitesi, Sağlık Bilimleri Fakültesi, Beslenme ve Diyetetik Bölümü

\section{Yazışma Adresi \\ Corresponding Address:}

Uzm. Dyt. Aysu Ayhan

\section{ORCID No: 0000-0002-6765-9892}

Başkent Üniversitesi, Sağlık Bilimleri Fakültesi, Beslenme ve Diyetetik Bölümü

E-posta: dytaysuayhan@gmail.com
Bu çalışma; profesyonel futbolcular ve voleybolcuların beslenme bilgi düzeyleri ve besin tüketim durumlarının değerlendirilmesi ile kafein alımları ve vücut kompozisyonları arasındaki ilişkinin karşılaştırılması amacıyla yapılmıştır. Çalışmaya; Türkiye Futbol Federasyonu (TFF) 1. Lig'de yer alan bir futbol kulübünde oynayan 19 futbolcu ile Türkiye Voleybol Federasyonu'na (TVF) bağlı iki farklı voleybol takımında oynayan 24 voleybolcu olmak üzere 18-35 yaş arası toplam 43 erkek sporcu katılmıștır. Sporcuların; sosyodemografik özellikleri, beslenme alışkanlıkları ve kafein alımları çoktan seçmeli soruların olduğu anket formuyla, beslenme bilgi düzeyleri ise Sporcu Beslenme Bilgisi Ölçeğ (SBBÖ) ile belirlenmiştir. Çalışmada voleybolcuların boy uzunluğu $(\mathrm{cm})$, vücut ağılığı $(\mathrm{kg})$ ve vücut yağ kütlesinin $(\mathrm{kg})$ futbolculara kıyasla daha yüksek olduğu görülmüştür $(p<0.05)$. Çalışmada futbolcuların enerji (kkal), karbonhidrat (\%), çoklu doymamış yağ asitleri (\%), posa $(\mathrm{g})$, A vitamini $(\mu \mathrm{g} / \mathrm{RE})$, E vitamini $(\mathrm{mg})$, tiamin $(\mathrm{mg})$, riboflavin $(\mathrm{mg})$, folat $(\mathrm{mcg}), \mathrm{C}$ vitamini $(\mathrm{mg})$ ve B6 vitamini $(\mathrm{mg})$, potasyum $(\mathrm{mg})$, kalsiyum $(\mathrm{mg})$, magnezyum $(\mathrm{mg})$ ve fosfor (mg) alımları voleybolculara göre daha yüksek bulunmuştur $(p<0.05)$. Çalışmada futbolcuların toplam günlük kafein alım miktarları ortalama $295.47 \pm 69.73 \mathrm{mg}$; voleybolcuların ise $347.53 \pm 238.62 \mathrm{mg}$ olduğu ve her iki grupta günlük kafein alımı ile vücut ağırlığı arasında negatif yönde bir ilişki olduğu görülmüş ancak istatistiksel açıdan anlamlı bulunmamıştır. Son olarak; voleybolcuların futbolculara kıyasla daha düşük beslenme bilgi düzeyine sahip olduğu $(p<0.05)$ ancak spor beslenmesi konusunda her iki grubun da "zayıf bilgi" düzeyine sahip olduğu belirlenmiştir. Bu çalışma sonuçları; futbolcular ve voleybolcuların beslenme bilgisi yetersizliğini gidermek, bu alandaki bilgilerini artırmak, beslenme alıskanlıklarını olumlu yönde değiștirmek ve buna bağlı olarak sportif performanslarını iyileştirmek için adımlar atılması gerektiğini göstermiştir.

Anahtar Kelimeler: Sporcu, Beslenme alıskanlıkları, Beslenme bilgisi, Kafein tüketimi

\section{ABSTRACT}

The aim of this study is to evaluate the nutritional knowledge and nutritional intake of professional football and volleyball players and to compare the relationship between caffeine intake and body composition. It was conducted on a total of 43 professional male athletes aged 18-35, 19 professional football players who played in a football team of Turkish Football Federation (TFF) 1st League and 24 professional volleyball players from two different volleyball teams of Turkish Volleyball Federation (TVF). A questionnaire was applied to the participants in order to determine their sociodemographic characteristics, general characteristics, dietary habits and caffeine intake. Nutritional knowledge levels of the participants were determined by Turkish version of the Nutrition for Sport Knowledge Questionnaire (NSKQ). It was observed that the height $(\mathrm{cm})$, body weight $(\mathrm{kg})$ and body fat mass $(\mathrm{kg})$ of volleyball players were higher than the football players $(\mathrm{p}<0.05)$. In this study, football players' energy (kcal), carbohydrate, polyunsaturated fatty acids (\%), pulp (g), vitamin $\mathrm{A}(\mu \mathrm{g} / \mathrm{RE})$, vitamin $\mathrm{E}(\mathrm{mg})$, thiamine $(\mathrm{mg})$, riboflavin $(\mathrm{mg})$, folate $(\mathrm{mcg})$, vitamin C $(\mathrm{mg})$, vitamin B6 $(\mathrm{mg})$, potassium $(\mathrm{mg})$, calcium $(\mathrm{mg})$, magnesium $(\mathrm{mg})$ and phosphorus $(\mathrm{mg})$ was higher than volleyball players $(\mathrm{p}<0.05)$. In this study, the average daily caffeine intake of football players was $295.47 \pm 69.73 \mathrm{mg}$; and that of volleyball players was $347.53 \pm 238.62$ $\mathrm{mg}$, and there was a negative relationship between daily caffeine intake and body weight in both groups, but it was not statistically significant. Finally; It was determined that volleybal players have lower nutritional knowledge level compared to football players $(p<0.05)$, but they have "less knowledge" level in both groups about sports nutrition. The results of this study; It has been shown that steps should be taken to eliminate the lack of nutritional knowledge of football players and volleyball players, to increase their knowledge in this field, to change their nutritional habits in a positive way and accordingly to improve their sportive performance.

Keywords: Athletes, Nutritional status, Nutritional knowledge, Caffeine consumption 
Profesyonel Futbol ve Voleybol Oyuncularının Beslenme Durumları, Beslenme Bilgi Düzeyleri, Kafein Alımları ve

Vücut Kompozisyonları Arasındaki İlișkinin Değerlendirilmesi

Evaluation of the Relationship Between Nutritional Status, Nutritional Knowledge, Caffeine Consumption and

Body Composition of Professional Soccer and Volleyball Players

\section{GíRiş}

Egzersiz performansı, belirli bir amaca ulaşmak için verilen sürede sporcu tarafından sergilenen çabaları tanımlamaktadır (Sağlık Bakanlığı, 2016). Egzersize adaptasyonun sağlanmasında; egzersizin süresi, türü ve yoğunluğu, egzersiz sıklığı, egzersiz öncesi ve sonrası dönemlerdeki beslenme kalitesi gibi çeşitli faktörlerin bir araya gelmesi belirleyici rol oynamaktadır. Beslenme ve egzersiz arasında sayısız etkileşim bulunmaktadır ve uzun dönemli egzersiz performansı sonuçlarının belirlenmesinde beslenmenin etkisi oldukça büyüktür (Jeukendrup, 2017).

Spor beslenmesi, spor bilimcilerinin, sporcuların, sporcu ailelerinin ve antrenörlerin doğru ve yeterli bilgi sahibi olması gereken ve son yıllarda üzerinde çok fazla çalışmanın yapıldığı bir alandır. Spor beslenmesinde en önemli hedef sporcunun genel sağlığını korumak, iyileştirmek ve performansını artırmak; sporcunun yaşına, cinsiyetine, enerji harcamasına, fiziksel aktivitesine ve beslenme alışkanlıklarına göre yeterli ve dengeli bir şekilde beslenmesini sağlamaktır (Baysal, 2014; Özdemir, 2010).

Beslenme bilgisi, diyet davranışlarının belirleyicilerinden biridir ve bireylerin besin alım düzeylerini etkilemektedir. Tüm bireylerde olduğu gibi sporcularda da doğru beslenme bilgisi, sporcuların sağlıkları hakkında bilinçli kararlar vermelerini sağlamaktadır (Jenner ve diğ., 2018). Sporcuların beslenme bilgisinin artması, daha sağlıklı beslenme alışkanlıkları kazanarak performans düzeylerinin artması ile ilişkilendirilmiştir. Bununla birlikte; cinsiyet, yaş, sosyodemografik özellikler ve eğitim düzeyi dahil olmak üzere birçok faktör beslenme bilgisini etkileyen demografik faktörler olarak tanımlanmıştır (Devlin ve diğ., 2017; Jenner ve diğ., 2018;). Atletik yetenek, egzersiz türü ve fiziksel kapasite başta olmak üzere, besin alımına odaklanmayı artırabilecek faktörlerin beslenme bilgisi ile ilişkili olduğunu gösteren bazı çalışmalar mevcuttur ancak beslenme bilgisi çok önemli bir faktör olarak kabul edilse de sporcuların besin

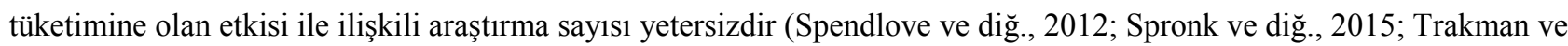
diğ., 2016).

Spor beslenmesi uzmanları, sporcuların beslenme bilgisi seviyelerini artırarak spor performanslarını da dolaylı olarak artırmayı amaçlamaktadır. Ergojenik yardımlar, sporcuların egzersiz verimliliğinin artmasına, toparlanma sürecinin hızlanmasına ve yoğun bir antrenman sırasında yaralanmayı önlemeye yardımcı olabilmektedir (Kerksick ve diğ., 2018).

Kafein, çeşitli spor dallarında, farklı rekabet seviyelerinde sporcular tarafından sıklıkla kullanılan ve egzersiz performansı üzerindeki etkinliği kanıtlanan, önemli ergojenik yararları sebebiyle giderek popüler hale gelen besin takviyelerinin başında yer almaktadır (Southward ve diğ., 2018; Tallis ve diğ., 2015). Elit sporcuların \%74'ünün bir spor müsabakası öncesinde veya sırasında kafein kullandıkları bildirilmiştir (Tallis ve diğ., 2015).

Kafeinin egzersiz performansı ile ilgili fizyolojik etkileri üzerine yapılmış çok sayıda çalışma bulunmaktadır; egzersiz veya atletik performansın iyileştirilmesinde kafein ile yapılan çalışmaların çoğu dayanıklılık, koşu ve bisiklet gibi submaksimal egzersiz aktivitelerine odaklanmıştır (Caldwell ve diğ., 2017; Desbrow ve diğ., 2012; Potgieter ve diğg., 2018; Ranchordas ve diğ., 2018). Bununla birlikte, anaerobik performansın ergojenik potansiyeli üzerine nispeten daha az araştırma bulunmaktadır (Duncan ve diğ., 2019; Stojanović ve diğ., 2019). Kafein, merkezi sinir sistemini uyarmas1, kas glikojenini koruması, kuvvet üretimini artırması, ağrı algısını azaltarak yorgunluğu geciktirmesi gibi ergojenik özellikleri nedeniyle sporcular tarafından yaygın olarak tüketilmektedir (Goldstein ve diğ., 2010).

Özetle, sporcuların üst düzey egzersiz performansına ulaşabilmeleri için, antrenman ve beslenme arasında güçlü bir etkileşim olduğu ve antrenmana adaptasyonlarda önemli bir rol oynadığı ortadadır. Bu noktada antrenman ve beslenmenin birbiri ile uyumlu ve sporcunun gereksinimlerine uygun olarak planlanması, sporcuların beslenme bilgi düzeylerinin doğru bir şekilde belirlenmesi ve buna yönelik eğitimlerin verilmesi, vücut kompozisyonu gibi fiziki özelliklerin spor dalına ve antrenman yoğunluğuna göre doğru bir şekilde belirlenmesi, bir sporcunun başarısındaki en önemli faktörler 
olarak görülmektedir ve üzerinde çalışılması gereken bir konu olarak önemini korumaktadır. Tüm bu veriler 1şığında bu çalışmanın amacı, futbol ve voleybol gibi farklı iki branştaki profesyonel sporcuların beslenme durumlarının değerlendirilmesi, beslenme bilgi düzeylerinin saptanması ve karşılaştırılması, kafein alım miktarlarının tespit edilmesi ve vücut kompozisyonları arasındaki ilişkinin değerlendirilmesidir.

\section{YÖNTEM}

Araştırma Grubu: Tanımlayıcı olarak planlanan bu araştırma, Aralık 2019 - Mart 2020 tarihleri arasında Türkiye Futbol Federasyonu 1. Lig'de yer alan bir futbol kulübünde oynayan profesyonel 19 futbolcu ve benzer demografik özelliklere sahip Türkiye Voleybol Federasyonuna bağlı iki farklı voleybol takımında bulunan profesyonel 24 voleybolcu olmak üzere 18-35 yaş arası toplam 43 erkek sporcu ile yapılmıştır. Değerlendirmelerin yapıldığı günlerde sakat olan oyuncular çalışmaya dahil edilmemiştir. Bu çalışma Başkent Üniversitesi Tıp ve Sağlık Bilimleri Araştırma Kurulu tarafından onaylanmış (Proje no:KA19/335, Tarih:23/10/2019) ve Helsinki Deklarasyonu Prensipleri’ne uygun bir şekilde yürütülmüştür.

Verilerin Toplanması: Araştırmaya dahil edilen sporcuların sosyodemografik özellikleri, genel özellikleri, besin tüketim durumları, beslenme alışkanlıkları ve kafein alım miktarlarının belirlenebilmesi amacıyla anket formu yüz yüze görüşme tekniği ile uygulanmıştır. Katılımcıların enerji ve besin ögesi alımlarının değerlendirilmesi için sporcuların 1 günü antrenman, 1 günü maç günü ve 1 günü antrenmansız güne denk gelecek şekilde 3 günlük besin tüketim kayıtları 24 saatlik hatırlatma yöntemi ile alınmıştır. Kayıt altına alınan besin tüketimleri Türkiye için geliştirilen "Bilgisayar Destekli Beslenme Programı (BEBİS)" paket programı kullanılarak analiz edilmiştir (Beslenme Bilgi Sistemleri, Dr. J. Erhardt, Stuttgart, Germany). Sporcuların üç günlük ortalama enerji ve besin ögesi verileri, yaşa ve cinsiyete göre önerilen “Diyetle Referans Alım Düzeyi” (Dietary Reference Intake=DRI)’ne göre değerlendirilmiştir (Institue of Medicine, 2005).

Sporcuların kafein tüketimlerinin değerlendirilebilmesi için, Otman (2017) tarafından hazırlanan araştırmadan uyarlanan Kafein Tüketim Sıklığı Kayıt Formu kullanılmıştır. Sezon içi dönemde, sporcuların geriye dönük son 1 ayı baz alınarak kaydedilen kafein tüketim sıklığı verilerinden diyetle ortalama günlük kafein alım miktarları belirlenmiştir.

Araştırmaya dahil edilen sporcuların antropometrik ölçümleri (boy uzunlukları (cm), vücut ağırlığı (kg)) ve vücut kompozisyonu analizleri (vücut yağ kütlesi (kg), vücut yağ yüzdesi (\%)) araştırmacı tarafından yapılmıştır. Sporcuların boy uzunlukları, ayaklar yan yana ve baş Frankfurt düzlemde (göz üçgeni ve kulak kepçesi üstü aynı hizada yere paralel) iken ölçülmüştür; ağırlık ölçümleri ise hafif giysili, ayakkabıları ve çorapları çıkartılarak baskül (Sinbo) yardımıyla yapılmıştır (Baysal ve diğ., 2014). Vücut kompozisyonu analizleri (vücut yağ kütlesi (kg), vücut yağ yüzdesi (\%)) için ise sporculardan alınan deri kıvrım kalınlıkları ölçüleri kullanılmıştır. Vücudun sağ tarafından Holtain LTD marka skinfold kaliper (Holtain Ltd., Crosswell, UK) ile 7 bölgeden (biseps, triseps, subskapula, göğüs, suprailiak, abdominal ve uyluk) deri kıvrım kalınlıkları alınmış ve Zorba (1989)'nın 7 bölge yağ yüzdesi formülüne yerleştirilerek bireylerin vücut yağ yüzdeleri (\%) hesaplanmıştır. Sporcuların fiziksel aktivite düzeyi, 1 günü antrenmanlı, 1 günü maç günü ve 1 günü izin gününe denk gelecek şekilde 24 saatlik fiziksel aktivite saptama formu ile kayıt altına alınmıştır ve her sporcuya özel ortalama fiziksel aktivite düzeyi (PAL) belirlenmiştir. Bireylerin PAL değerleri Gıda ve Tarım Örgütü/Dünya Sağlık Örgütü/Birleşmiş Milletler Üniversitesi FAO/WHO/UNU (2001) raporuna göre değerlendirilmiştir ve bazal metabolizma hızının belirlenmesinde FAO/WHO/UNU denklemi kullanılmıştır. Bireylerin enerji gereksinimleri, bazal metabolizma hızı $(\mathrm{BMH})$ ve fiziksel aktivite faktörü dikkat alınarak hesaplanmıştır. 


\section{Veri Toplama Araçları:}

Sporcu beslenme bilgisi ölçeği: Sporcuların beslenme bilgi düzeyleri, Türkçe geçerlik ve güvenirliği 2019 yılında Çırak (2019) tarafından yapılan Sporcu Beslenme Bilgisi Ölçeği (SBBÖ) ile belirlenmiştir. Ölçek, 68 madde; Ağırlık Kontrolü (3 madde), Makro Besin Ögeleri (22 madde), Mikro Besin Ögeleri (12 madde), Spor Beslenmesi (11 madde), Suplemanlar (11 madde), ve Alkol ( 9 madde) olmak üzere 6 alt boyuttan oluşan ölçeğin maddeleri çoktan seçmeli ve 3'lü likert tipidir (katılıyorum-katılmıyorum-emin değilim; etkili-etkili değil-emin değilim). Ölçeğin puanlaması için, verilen doğru cevaplardan bilgi puanları hesaplanmakta ve SBBÖ'deki genel performans (68 madde 100 puan olarak kabul edilir) skorlama sistemi kullanılarak; "Zayıf” bilgi (\%0-49), "ortalama" bilgi (\%50-65), "iyi” bilgi (\%66-75) ve “mükemmel" bilgi (\%76-100) şeklinde değerlendirilmektedir.

Verilerin Analizi: Verilerin istatistiksel değerlendirilmesinde SPSS 23.0 istatistik paket programı kullanılmıştır (SPSS Inc., Chicago, IL, ABD). Sürekli değişkenlerin normal dağılıma uygunluğu 'Kolmogorov- Simirnov" testi ile değerlendirilmiştir. Bağımsız iki veya daha fazla değişken grubu arasında kategorik değişkenlerin karşılaştırılmasında "Ki - Kare testi” uygulanmıştır. Bağımsız iki grubun ortalamalarının karşılaştırılmasında parametrik test varsayımları sağlandığında "Bağımsız Gruplarda T-Testi”, parametrik test varsayımları sağlanmayan değişkenler için "Mann Whitney U Testi” kullanılmıştır. Normal dağılım gösteren ikiden fazla grubun karşılaştırılmasında, tekrarlı ölçümlerin ortalamaları “Tekrarlı Ölçümlerde Varyans Analizi” ile değerlendirilmiştir. İki sayısal değişken arasında ilişki olup olmadığının araştırılması ve varsa bu ilişkinin yönünün ve şiddetinin belirlenmesi için 'Pearson korelasyon analizi" ve "Spearman korelasyon analizi" kullanılmıştır. Bütün hipotez testlerinin analizlerinde istatistiksel anlamlılık düzeyi $p<0.05$ olarak alınmıştır.

\section{BULGULAR}

Çalışmaya katılan sporculara ait genel özellikler, beslenme alışkanlıkları ve antropometrik ölçümlere ilişkin veriler Tablo 1'de gösterilmiştir. Buna göre; futbolcuların yaş ortalaması 23.26 \pm 3.69 yıl, voleybolcuların $25.37 \pm 4.44$ yıldır. Voleybolcuların boy uzunluğu $(\mathrm{cm})$, vücut ağırlığı $(\mathrm{kg})$ ve yağ kütlesinin $(\mathrm{kg})$ futbolculara kıyasla daha yüksek olduğu görülmüştür ( $\mathrm{p}<0.001)$.

Sporcuların genel beslenme alışkanlıkları değerlendirildiğinde; futbolcuların \%94.7'si, voleybolcuların ise \%70.8'i günde 3 ana öğün tüketirken, voleybolcuların \%29.2'sinin öğün atladığı görülmüştür ve voleybolcular genel olarak sabah (\%42.9) ve öğle (\%42.9) öğününü atlamaktadır. Futbolcular sabah ve öğle öğünlerini atlamamaktadır (Tablo 1).

Sporcuların ara öğün tüketim alışkanlıkları değerlendirildiğinde futbolcuların \%52.6'sının bir ara öğün, \%42.1'inin iki ara öğün, \%5.3'ünün üç ara öğün; voleybolcuların ise \%62.5'inin bir ara öğün, \%37.5'inin iki ara öğün tükettiği belirlenmiştir. Ayrıca futbolcuların \%47.4'ünün voleybolcuların \%29.2'sinin ergojenik destek (protein tozu, glukozamin, dekstroz vb.) kullandığı belirlenmiştir. Her iki grupta beslenme alışkanlıkları açısından istatistiksel olarak anlamlı farkl11ıklar gözlemlenmemiştir ( $\mathrm{p}>0.05)$ (Tablo 1). 
Tablo 1

$\underline{\text { Sporcuların Genel Özellikleri, Beslenme Alışkanlıklarl ve Antropometrik Ölçümlerine İlişkin Verilerin Değerlendirilmesi }}$ Futbolcu $(\mathbf{n}=19)$ Voleybolcu $(\mathbf{n}=24)$

\begin{tabular}{|c|c|c|c|c|c|}
\hline & \multicolumn{2}{|c|}{$\overline{\mathbf{X}} \pm \mathbf{S S}$} & \multicolumn{2}{|c|}{$\overline{\mathbf{X}} \pm \mathbf{S S}$} & $\mathbf{p}$ \\
\hline Yaș (yıl) & \multicolumn{2}{|c|}{$23.26 \pm 3,69$} & \multicolumn{2}{|c|}{$25.37 \pm 4,44$} & 0.103 \\
\hline Antropometrik Ölçümler & & \multirow{2}{*}{\multicolumn{2}{|c|}{$197.95 \pm 6.67$}} & \\
\hline Boy uzunluğu(cm) & \multirow{2}{*}{\multicolumn{2}{|c|}{$\begin{array}{c}178.78 \pm 5.46 \\
74.70 \pm 4.43\end{array}$}} & & & $<0.001^{*}$ \\
\hline Vücut ağırlığı (kg) & & & \multicolumn{2}{|c|}{$93.42 \pm 9.32$} & $<0.001^{*}$ \\
\hline \multicolumn{6}{|l|}{ Vücut Kompozisyonu } \\
\hline Yağ yüzdesi (\%) & \multirow{2}{*}{\multicolumn{2}{|c|}{$\begin{array}{l}7.15 \pm 1.01 \\
5.36 \pm 0.93\end{array}$}} & \multirow{2}{*}{\multicolumn{2}{|c|}{$\begin{array}{l}7.71 \pm 1.08 \\
7.22 \pm 1.30\end{array}$}} & 0.090 \\
\hline \multirow[t]{2}{*}{ Yağ kütlesi (kg) } & & & & & $<0.001^{*}$ \\
\hline & $\mathbf{S}$ & $\%$ & $\mathbf{S}$ & $\%$ & \\
\hline \multicolumn{6}{|l|}{ Beslenme Alışkanlıkları } \\
\hline Ana öğün & & & & & 0.059 \\
\hline 2 & 1 & 5.3 & 7 & 29.2 & \\
\hline 3 & 18 & 94.7 & 17 & 70.8 & \\
\hline Ara öğün & & & & & 0.630 \\
\hline 1 & 10 & 52.6 & 15 & 62.5 & \\
\hline 2 & 8 & 42.1 & 9 & 37.5 & \\
\hline 3 & 1 & 5.3 & - & - & \\
\hline Öğün atlama & & & & & 0.059 \\
\hline Atliyor & 1 & 5.3 & 7 & 29.2 & \\
\hline Atlamiyor & 18 & 94.7 & 17 & 70.8 & \\
\hline Atlanan ana öğün & & & & & 0.250 \\
\hline Sabah & - & - & 3 & 42.9 & \\
\hline Öğle & - & - & 3 & 42.9 & \\
\hline Akşam & 1 & 100.00 & 1 & 14.3 & \\
\hline Ergojenik destek kullanma & & & & & 0.220 \\
\hline Kullanıyor & 9 & 47.4 & 7 & 29.2 & \\
\hline Kullanmiyor & 10 & 52.6 & 17 & 70.8 & \\
\hline
\end{tabular}
$* \mathrm{p}<0.001$

Çalışmaya katılan sporcuların enerji, makro ve mikro besin ögeleri alımlarına ilişkin veriler Tablo 2'de gösterilmektedir. Buna göre; futbolcuların günlük diyetleriyle toplam enerji alımlarının \%45.31 \pm 5.99 ’u karbonhidratlardan, \%17.05 \pm 2.41 'i proteinlerden, \%40.63 \pm 6.52 'si yağlardan; voleybolcuların ise toplam enerji alımlarının \%36.62 \pm 8.15 'i karbonhidratlardan, \%23.91 \pm 3.18 'i proteinlerden ve \%38.45 \pm 7.59'u yağlardan gelmektedir. Futbolcuların enerji (kkal), karbonhidrat (\%), çoklu doymamış yağ asitleri (\%) ve posa (g) alımlarının voleybolculardan daha yüksek olduğu görülmüştür $(\mathrm{p}<0.05)$.

Sporcuların mikro besin ögesi alımları değerlendirildiğinde ise; futbolcuların günlük diyetleriyle A vitamini $(\mu \mathrm{g} / \mathrm{RE})$, E vitamini $(\mathrm{mg})$, tiamin $(\mathrm{mg})$, riboflavin $(\mathrm{mg})$, folat $(\mathrm{mcg}), \mathrm{C}$ vitamini $(\mathrm{mg})$ ve B6 vitamini $(\mathrm{mg})$, potasyum (mg), kalsiyum (mg), magnezyum (mg) ve fosfor (mg) alımları voleybolculara göre daha yüksek bulunmuştur ( $\mathrm{p}<0.05$ ). Futbolcuların mikro besin ögesi alımları DRI önerilerine göre değerlendirildiğinde alım düzeylerinin yeterli veya yüksek olduğu saptanmıştır; voleybolcuların ise tiamin, folat ve C vitamini, potasyum, kalsiyum ve magnezyum alımlarının DRI önerilerine göre yetersiz olduğu belirlenmiştir (Tablo 2). 


\section{Tablo 2}

Sporcuların Enerji, Makro ve Mikro Besin Ögeleri Alımlarının Değerlendirilmesi

\begin{tabular}{|c|c|c|c|c|c|}
\hline \multirow{2}{*}{$\begin{array}{l}\text { Enerji, Makro ve Mikro Bes } \\
\text { Ögeleri }\end{array}$} & \multicolumn{2}{|c|}{ Futbolcu $(n=19)$} & \multicolumn{2}{|c|}{ Voleybolcu $(n=24)$} & \\
\hline & \multicolumn{2}{|c|}{$\overline{\mathbf{X}} \pm \mathbf{S S}$} & \multicolumn{2}{|c|}{$\overline{\mathbf{X}} \pm \mathbf{S S}$} & $\mathbf{p}$ \\
\hline Enerji (kkal) & \multicolumn{2}{|c|}{$3344.87 \pm 741.50$} & \multicolumn{2}{|c|}{$2548.43 \pm 550.00$} & $<0.001 *$ \\
\hline \multicolumn{6}{|l|}{ Makro Besin Ögeleri } \\
\hline Karbonhidrat (g) & \multicolumn{2}{|c|}{$337.53 \pm 85.33$} & \multicolumn{2}{|c|}{$232.76 \pm 65.01$} & $<0.001 *$ \\
\hline Karbonhidrat (TE\%) & \multicolumn{2}{|c|}{$45.31 \pm 5.99$} & \multicolumn{2}{|c|}{$36.62 \pm 8.15$} & $<0.001 *$ \\
\hline Karbonhidrat (g/kg) & \multicolumn{2}{|c|}{$5.12 \pm 1.16$} & \multicolumn{2}{|c|}{$2.50 \pm 0.71$} & $<0.001^{*}$ \\
\hline Protein $(g)$ & \multicolumn{2}{|c|}{$134.97 \pm 28.57$} & \multicolumn{2}{|c|}{$150.36 \pm 40.44$} & 0.160 \\
\hline Protein (TE\%) & \multicolumn{2}{|c|}{$17.05 \pm 2.41$} & \multicolumn{2}{|c|}{$23.91 \pm 3.18$} & $<0.001 *$ \\
\hline Protein $(\mathrm{g} / \mathrm{kg})$ & \multicolumn{2}{|c|}{$1.80 \pm 0.38$} & \multicolumn{2}{|c|}{$1.61 \pm 0.44$} & 0.100 \\
\hline Yağ (g) & \multicolumn{2}{|c|}{$150.97 \pm 45.71$} & \multicolumn{2}{|c|}{$110.80 \pm 35.06$} & $0.002 * *$ \\
\hline Yağ (TE\%) & \multicolumn{2}{|c|}{$40.63 \pm 6.52$} & \multicolumn{2}{|c|}{$38.45 \pm 7.59$} & 0.328 \\
\hline Doymuş yağ asidi (\%) & \multicolumn{2}{|c|}{$11.69 \pm 1.83$} & \multicolumn{2}{|c|}{$13.38 \pm 1.90$} & $<0.001 *$ \\
\hline Çoklu doymamış yağ asidi (\%) & \multicolumn{2}{|c|}{$10.91 \pm 3.77$} & \multicolumn{2}{|c|}{$8.09 \pm 3.09$} & $0.010 * *$ \\
\hline Tekli doymamış yağ asidi (\%) & \multicolumn{2}{|c|}{$14.58 \pm 3.30$} & \multicolumn{2}{|c|}{$15.20 \pm 3.56$} & 0.561 \\
\hline Posa $(g)$ & $26.30 \pm 7$ & & $21.03 \pm 7$ & & $0.022 * *$ \\
\hline & $\overline{\mathbf{X}} \pm \mathbf{S S}$ & $\operatorname{DRI}(\%)$ & $\overline{\mathbf{X}} \pm \mathbf{S S}$ & $\operatorname{DRI}(\%)$ & \\
\hline Mikro besin ögeleri & & & & & \\
\hline A vitamini $(\mu \mathrm{g} / \mathrm{RE})$ & $1350.16 \pm 389.69$ & 150.02 & $1010.71 \pm 322.01$ & 112.30 & $0.003 * *$ \\
\hline E vitamini (mg) & $29.23 \pm 12.18$ & 194.88 & $16.79 \pm 8.14$ & 111.90 & $<0.001 *$ \\
\hline Tiamin (mg) & $1.49 \pm 0.41$ & 123.99 & $0.97 \pm 0.25$ & 81.04 & $<0.001 *$ \\
\hline Riboflavin (mg) & $2.21 \pm 0.56$ & 170.08 & $1.79 \pm 0.50$ & 137.47 & $0.012 * *$ \\
\hline Niasin (mg) & $23.14 \pm 7.09$ & 144.63 & $26.45 \pm 8.49$ & 165.34 & 0.180 \\
\hline Folat (mcg) & $411.57 \pm 113.14$ & 102.89 & $353.08 \pm 64.84$ & 88.27 & $0.039 * *$ \\
\hline $\mathrm{B}_{12}$ vitamini (mcg) & $8.15 \pm 2.19$ & 339.47 & $6.79 \pm 2.58$ & 283.06 & 0.075 \\
\hline C vitamini (mg) & $191.05 \pm 95.75$ & 231.58 & $65.38 \pm 33.67$ & 79.24 & $<0.001 *$ \\
\hline $\mathrm{B}_{6}$ vitamini (mg) & $2.43 \pm 0.92$ & 186.52 & $1.95 \pm 0.51$ & 149.97 & $0.036 * *$ \\
\hline Potasyum (mg) & $3930.72 \pm 1192.54$ & 122.84 & $2620.40 \pm 642.76$ & 81.89 & $<0.001^{*}$ \\
\hline Kalsiyum (mg) & $1168.26 \pm 336.01$ & 101.59 & $636.92 \pm 166.08$ & 55.38 & $<0.001 *$ \\
\hline Magnezyum (mg) & $469.63 \pm 137.48$ & 114.54 & $362.92 \pm 93.64$ & 88.52 & $0.004 * *$ \\
\hline Fosfor (mg) & $2145.81 \pm 521.01$ & 220.08 & $1811.76 \pm 400.62$ & 185.82 & $0.022 * *$ \\
\hline Demir (mg) & $17.83 \pm 4.46$ & 187.63 & $16.47 \pm 4.10$ & 173.55 & 0.313 \\
\hline Çinko (mg) & $18.43 \pm 4.20$ & 167.52 & $17.98 \pm 6.40$ & 163.48 & 0.448 \\
\hline
\end{tabular}

$* \mathrm{p}<0.001 * * \mathrm{p}<0.05$

Çalışmaya katılan sporculara uygulanan Sporcu Beslenmesi Bilgi Ölçeğinden (SBBÖ) elde edilen sonuçlar Tablo 3 'te gösterilmektedir. Buna göre; çalışmaya katılan futbolcuların ve voleybolcuların sırasıyla SBBÖ puanları ortalama $23.57 \pm 4.64$ ve $17.29 \square 8.20$ puan olup, futbolcuların beslenme bilgi düzeylerinin voleybolculardan daha yüksek olduğu görülmüştür $(\mathrm{p}<0.05)$. Sporcuların SBBÖ ortalama puanları sınıflandırıldığında ise tüm sporcuların (\%100) spor beslenmesi konusunda "zayıf bilgi”" düzeyine sahip olduğu belirlenmiştir.

Sporcuların bazı demografik özellikleri ve vücut kompozisyonları ile SBBÖ toplam puanı arasındaki ilişkileri değerlendirildiğinde ise; futbolcuların yaş $(r=0.198, p=0.417)$, eğitim durumu $(r=0.216, p=0.681)$ ve beslenme eğitimi alma durumu $(r=0.288, p=0.231)$ arasında; voleybolcuların ise yaş $(r=0.099, p=0.644)$ ve eğitim durumu $(r=0.054, p=$ 0.801) arasında ise pozitif yönde bir ilişki olduğu belirlenmiş ancak istatistiksel açıdan anlamlı bulunmamıştır ( $\mathrm{p}>0.05$ ). Yaş ve eğitim durumu arttıkça SBBÖ toplam puanının arttığı saptanmıştır. Futbolcuların SBBÖ toplam puanı ile vücut ağırlığ1 $(r=-0.049, p=0.843)$, vücut yağ yüzdesi $(r=-0.034, p=0.891)$ ve vücut yağ kütlesi $(r=-0.044, p=0.857)$ arasında negatif yönde bir ilişki; voleybolcuların ise SBBÖ toplam puanı ile vücut ağırlığı $(r=0.274, p=0.194)$, vücut yağ yüzdesi 
$(r=0.130, p=0.546)$ ve vücut yağ kütlesi $(r=0.251, p=0.237)$ arasında pozitif yönde bir ilişki olduğu belirlenmiş ancak bu ilişkiler istatistiksel olarak anlamlı bulunmamıştır $(\mathrm{p}>0.05)$ (Tablo 3).

Tablo 3

Sporcuların SBBÖ Puanlarl ile Bazl Demografik Özellikleri ve Vücut Kompozisyonları Arasındaki İlişkinin Değerlendirilmesi

\begin{tabular}{|c|c|c|c|c|c|c|}
\hline & \multicolumn{2}{|c|}{ Futbolcu (n=19) } & \multicolumn{2}{|c|}{ Voleybolcu $(n=24)$} & $\begin{array}{c}\text { Toplam } \\
(n=43)\end{array}$ & $\mathbf{p}$ \\
\hline SBBÖ Puanı, $\mathrm{X} \pm \mathrm{SS}$ & \multicolumn{2}{|c|}{$23.57 \pm 4.64$} & \multicolumn{2}{|c|}{$17.29 \pm 8.20$} & $20.06 \pm 7.49$ & $0.003 * *$ \\
\hline SBBÖ Puanı & $\mathbf{r}$ & $\mathbf{p}$ & $\mathbf{r}$ & $\mathbf{p}$ & & \\
\hline Yaş & 0.198 & 0.417 & 0.099 & 0.644 & & \\
\hline Eğitim durumu & 0.216 & 0.681 & 0.054 & 0.801 & & \\
\hline Beslenme eğitimi alma durumu & 0.288 & 0.231 & -0.369 & 0.076 & & \\
\hline Vücut ağırlığ1 & -0.049 & 0.843 & 0.274 & 0.194 & & \\
\hline Vücut yağ yüzdesi & -0.034 & 0.891 & 0.130 & 0.546 & & \\
\hline Vücut yağ kütlesi & -0.044 & 0.857 & 0.251 & 0.237 & & \\
\hline
\end{tabular}

$* * \mathrm{p}<0.05$

Çalışmaya katılan sporcuların günlük kafein alımlarının değerlendirilmesi Tablo 4'te verilmiştir. Buna göre; futbolcuların toplam kafein alımlarının ortalaması $295.47 \pm 69.73 \mathrm{mg}$, voleybolcuların ise $347.53 \pm 238.62 \mathrm{mg}$ olarak saptanmıştır ( $>0.05)$. Futbolcuların vücut ağırlıkları $(\mathrm{kg})$ başına aldıkları ortalama kafein miktarı $3.97 \pm 1.00 \mathrm{mg} / \mathrm{kg}$, voleybolcuların ise $3.70 \pm 2.37 \mathrm{mg} / \mathrm{kg}$ 'dır $(\mathrm{p}>0.05)$.

Futbolcularda en sık tüketilen kafein kaynaklarının sırasıyla çay (\%41.34), kahve (\%35.54), kolalı içecekler (\%10.30) ve çikolata (\%5.21) olduğu; voleybolcularda ise en sık tüketilen kafein kaynağının kahve çeşitleri (\%77.97) olduğu belirlenmiştir. Gruplara göre kafein kaynakları arasında çay, çikolata, bisküvi/kek ve kolalı içeceklerin tüketim miktarları arasındaki farklar istatistiksel açıdan anlamlı olup futbolcuların günlük diyetleriyle aldıkları kafein miktarı voleybolculara kıyasla yüksek bulunmuştur $(\mathrm{p}<0.05)$ (Tablo 4).

Tablo 4.

Sporcuların Günlük Kafein Alımlarının Değerlendirilmesi (mg/gün)

\begin{tabular}{|c|c|c|c|c|c|}
\hline \multirow{2}{*}{$\begin{array}{l}\text { Diyette en sık tüketilen kafein } \\
\text { kaynakları }\end{array}$} & \multicolumn{2}{|c|}{ Futbolcu (n=19) } & \multicolumn{3}{|c|}{ Voleybolcu (n=24) } \\
\hline & \multicolumn{2}{|c|}{$\mathrm{X} \pm \mathrm{SS}$} & \multicolumn{2}{|c|}{$\mathrm{X} \pm \mathrm{SS}$} & $\mathbf{p}$ \\
\hline Kahve (mg) & \multicolumn{2}{|c|}{$105.00 \pm 57.47$} & \multicolumn{2}{|c|}{$270.98 \pm 235.14$} & 0.023 \\
\hline Çay (mg) & \multicolumn{2}{|c|}{$122.14 \pm 18.82$} & \multicolumn{2}{|c|}{$34.58 \pm 28.63$} & $<0.001^{*}$ \\
\hline Çikolatalı içecekler (mg) & \multicolumn{2}{|c|}{$1.16 \pm 3.33$} & \multicolumn{2}{|c|}{$0.13 \pm 0.28$} & 0.931 \\
\hline Dondurma (mg) & \multicolumn{2}{|c|}{$0.27 \pm 0.65$} & \multicolumn{2}{|c|}{$0.05 \pm 0.12$} & 0.369 \\
\hline Çikolata (mg) & \multicolumn{2}{|c|}{$15.39 \pm 11.38$} & \multicolumn{2}{|c|}{$5.98 \pm 9.09$} & $0.001 *$ \\
\hline Bisküvi/Kek (mg) & \multicolumn{2}{|c|}{$14.57 \pm 11.06$} & \multicolumn{2}{|c|}{$2.54 \pm 3.42$} & $<0.001 *$ \\
\hline Kolalı içecekler (mg) & \multicolumn{2}{|c|}{$30.44 \pm 23.46$} & \multicolumn{2}{|c|}{$18.79 \pm 36.10$} & $0.004 * *$ \\
\hline Enerji içecekleri (mg) & \multicolumn{2}{|c|}{$6.47 \pm 9.67$} & \multicolumn{2}{|c|}{$14.45 \pm 23.18$} & 0.445 \\
\hline Toplam kafein (mg/gün) & \multicolumn{2}{|c|}{$295.47 \pm 69.73$} & \multicolumn{2}{|c|}{$347.53 \pm 238.62$} & 0.980 \\
\hline Toplam kafein (mg/kg) & \multicolumn{2}{|c|}{$3.97 \pm 1.00$} & \multicolumn{2}{|c|}{$3.70 \pm 2.37$} & 0.619 \\
\hline Toplam kafein alımı & $\mathbf{r}$ & $\mathbf{p}$ & $\mathbf{r}$ & $\mathbf{p}$ & \\
\hline Vücut ağırlığı $(\mathrm{kg})$ & -0.206 & 0.398 & -0.023 & 0.916 & \\
\hline Vücut yağ yüzdesi (\%) & 0.221 & 0.363 & -0.344 & 0.100 & \\
\hline Vücut yağ kütlesi $(\mathrm{kg})$ & 0.117 & 0.634 & -0.154 & 0.473 & \\
\hline
\end{tabular}

$* \mathrm{p}<0.001 * * \mathrm{p}<0.05$ 
Profesyonel Futbol ve Voleybol Oyuncularının Beslenme Durumları, Beslenme Bilgi Düzeyleri, Kafein Alımları ve

Vücut Kompozisyonları Arasındaki İlișkinin Değerlendirilmesi

Evaluation of the Relationship Between Nutritional Status, Nutritional Knowledge, Caffeine Consumption and

Body Composition of Professional Soccer and Volleyball Players

Sporcuların vücut kompozisyonları (VA, Vücut yağ yüzdesi, Vücut yağ kütlesi) ile günlük kafein alımları arasındaki ilişki değerlendirildiğinde ise; futbolcuların günlük kafein alımları ile vücut ağırlıkları $(r=-0.206, p=0.398)$ arasında; voleybolcuların ise vücut ağırlıkları $(r=-0.023, p=0.916)$, vücut yağ kütleleri $(r=-0.344, p=0.100)$ ve vücut yağ yüzdeleri $(\mathrm{r}=-0.154, \mathrm{p}=0.473)$ arasında negatif yönde istatistiksel ilişki olduğu görülmüş ancak istatistiksel açıdan anlamlı bulunmamıştır ( $>0.05$ ) (Tablo 4).

\section{TARTIŞMA}

Takım sporları; tekrarlayan, kısa süreli yüksek yoğunluklu aktivite periyotlarını içeren ve aynı zamanda düşük yoğunluklu egzersizler ile karakterize olan "dur-kalk" oyun şeklinden oluşmaktadır (Williams ve Rollo, 2015). Düzenli egzersiz ile tüm spor dallarında yarışan sporcular, ihtiyaçları doğrultusunda ve oynadıkları pozisyonlara göre değişen ekstra besin ve besin ögesi alımına ihtiyaç duyarken, toplam enerji harcaması yapılan egzersizin şiddeti ile orantılı olarak artı̧s göstermektedir (Miškulin ve diğ., 2019). Yeterli düzeyde besin alımı için öncelikli olarak sporcuların günlük enerji ihtiyaçlarının karşılanması ve uygun rekabet ortamında yarışabilmeleri için ihtiyaçlarını karşılayacak şekilde özelleştirilmesi gerekmektedir (Miškulin ve diğ., 2019; Williams ve Rollo, 2015).

Bu çalışmada sporcuların fiziksel aktivite kayıtlarına göre günlük enerji ihtiyaçları hesaplanmış; futbolcuların yeterli enerji (3344.87 $\pm 741.50 \mathrm{kkal})$ aldıkları, voleybolcuların ise almaları gereken enerjiye göre yetersiz düzeyde enerji $(2548.43 \pm 550.00 \mathrm{kkal})$ aldıkları görülmüştür $(\mathrm{p}<0.05)$. Negatif enerji dengesi kas kaybı, yorgunluk, yaralanmalar gibi birçok soruna sebep olabilir. Ayrıca yetersiz enerji alımı sonucu gelişebilecek sağlık sorunları egzersiz performansını da olumsuz yönde etkileyebilmektedir (Jenner ve diğ., 2018).

Takım sporlarının aerobik yapısı ve süresine bağlı olarak, sporcuların performanslarını en üst düzeye çıkarmaları ve antrenman sonrası toparlanmayı sağlamaları için karbonhidrat alım düzeyi oldukça önemlidir (Trakman ve diğ., 2016). Amerikan Spor Hekimliği Birliği (ACSM)'ne göre takım sporcularında günlük karbonhidrat gereksinimi 7-8 g/kg VA (standart bir sporcu için 500-600 g/gün) olarak belirlenmiş̧tir (Thomas ve diğ., 2016). ACSM sporcular için günlük protein gereksinimini ise 1.2-1.7 g/kg VA, Uluslararası Spor Beslenmesi Komitesi (ISSN) ise 1.4-2.0 g/kg VA olarak belirlemiştir (Kreider ve diğ., 2010). Bu araştırmada futbolcuların günlük karbonhidrat alımları 5.12 $\pm 1.16 \mathrm{~g} / \mathrm{kg}$ VA; voleybolcuların $2.50 \pm 0.71 \mathrm{~g} / \mathrm{kg}$ VA olarak belirlenmiştir. Futbolcuların protein alım miktarları ise $1.80 \pm 0.38 \mathrm{~g} / \mathrm{kg}$ VA; voleybolcuların $1.61 \pm 0.44 \mathrm{~g} / \mathrm{kg}$ VA'dır. Bu sonuçlar ACSM Kılavuzu önerilere göre değerlendirildiğinde; sporcuların tamamının protein alım miktarları önerilen düzeyler arasındayken karbonhidrat alım miktarlarının yetersiz olduğu görülmektedir. Sporcuların performans öncesinde ve sırasında yeterli miktarda karbonhidrat tüketmesi son derece önemlidir. Yoğun bir antrenman sırasında yeterli karbonhidrat alımı performans ve ruh hali üzerine iyileştirici etkiler göstermiştir (Burke ve diğ., 2016). Karbonhidratların organizmada temel yakıt kaynağı olması ve performans üzerine olumlu etkilerine karşın sporcuların önerilen karbonhidrat miktarını karşılamada yetersiz oldukları bilinmektedir (Burke, 2008). Örneğin yapılan bir çalışmada futbolcuların $3 \mathrm{~g} / \mathrm{kgVA} /$ gün karbonhidrat aldıkları ve bu alımın yetersiz olduğu bildirilmiştir (Fink ve Mikesky, 2006). Benzer şekilde basketbolcularda yapılan bir çalışmada da karbonhidrat alımının $2.51 \mathrm{~g} / \mathrm{kgVA} / \mathrm{gün}$ olduğu belirlenmiştir (Papadopoulou ve diğ.,2008). Benzer şekilde bu çalışmada da sporcuların tamamında karbonhidrat alımının yetersiz olduğu buna bağlı olarak yağ alımlarının yüksek olduğu görülmektedir.

Spor beslenmesinde yağlar için belirlenmiş net bir gereksinim ve öneri değeri bulunmamakla beraber genel popülasyondan (TE \%20-35) çok da farklı olmayan önerilerin yapıldığı çalışmalar bulunmaktadır (Spendlove ve diğ., 2012; Spronk ve diğ., 2015; Trakman ve diğ., 2016). Ancak karbonhidrat alımı düştükçe toplam enerjinin yağdan gelen oranı yükselmektedir. Bu çalışmada; futbolcularda toplam enerjinin $\% 40.63 \pm 6.52$ 'si, voleybolcularda ise $\% 38.45 \pm 7.59$ 'i yağlardan gelmekte ve futbolcuların toplam yağ alımının $\% 11.69 \pm 1.83$ 'u, voleybolcuların ise $\% 13.38 \pm 1.90$ 'u doymuş 
yağlardan oluşmaktadır. Sporcularda önerilerin üzerinde yağ alımı vücut yağ dokusunun artmasına bu durumda ileriki dönemde ağırlık artışına ve performansın azalmasına neden olabilir. Aynı zamanda özellikle doymuş yağ alımının artışı ileriki dönemde kardiyovasküler hastalık gelişim riskini de arttırabilir (Rodriguez ve diğ.,2009).

Sporcuların mikro besin öğeleri alım miktarları değerlendirildiğinde, futbolcuların tüm mikro besin ögesi gereksinimlerinin karşılandığı; voleybolcuların ise tiamin, folat, C vitamini, potasyum, kalsiyum ve magnezyum alımlarının yetersiz olduğu saptanmıştır. Mikro besin öğelerinin tamamının önerilen düzeyde alınması başta enerji metabolizması olmak üzere, bağışıklık sistemi, antrenman veya müsabaka sonrası kas toparlanması, hemoglobin sentezi ve organizmdaki oksidatif hasara karşı korunmada oldukça önemlidir (Mastaloudis ve diğ., 2006).

Takım sporlarında fiziksel performansın iyileştirilmesi için beslenme bilgisi, besin çeşitliliği ve vücut kompozisyonu gibi değiştirilebilir faktörler üzerinde yapılacak iyileştirmeler oldukça önemlidir (Devlin ve diğ., 2017). Temel varsayım, daha sağlıklı beslenme alışkanlıkları kazanmak için yeterli beslenme bilgisi, doğru besin seçimi ve hazırlık becerilerine ihtiyaç duyulduğu ve bu alanlarda verilecek eğitimin davranışsal değişimlere yol açacağıdır (Spendlove ve diğ., 2012). Spor beslenmesinde yapılacak düzenlemeler, performans üzerine doğrudan etkili olmasından dolayı giderek önem kazanmaktadır (Lohman ve diğ., 2019). Özellikle sporcularda beslenme bilgisinin değerlendirilmesi ve bunun sonucunda beslenme eğitiminin geliştirilmesi de oldukça önemlidir (Heaney ve diğ., 2011).

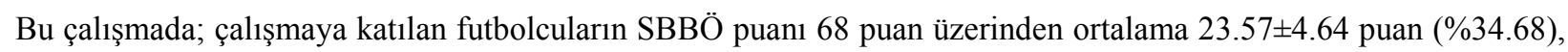
voleybolcuların ise ortalama $17.29 \pm 8.20$ puan $(\% 25.43)$ bulunmuştur $(\mathrm{p}<0.05)$. SBBÖ puanları, doğru beslenme bilgisi sorularının sayısından hesaplandıktan sonra doğru cevaplanan soru sayısı yüzde olarak dönüştürüldüğünde, her iki gruptaki sporcuların tamamının spor beslenmesi konusunda "zayıf bilgi (\%0-49)" düzeyine sahip olduğu belirlenmiş̧ir.

Yaş ortalaması $24.2 \pm 4.0$ olan profesyonel futbolcularla $(n=46)$ yürütülen bir çalışmada; katılımcıların ortalama beslenme bilgi puanı, 89 puan üzerinden $41 \pm 13$ (\%46 ortalama puan) bulunmuştur ve bu çalışmadaki bulgulara benzer olarak; sporcuların genel beslenme bilgisinin zayıf düzeyde olduğu saptanmıştır (Jenner ve diğ., 2018). Hırvatistan'da yapılan 19-24 yaş arası 211 elit ve amatör sporcunun beslenme bilgilerinin karşılaştırıldığı bir çalışmada; sadece bir katılımcının (\%0.5) beslenme bilgisi "iyi bilgi" düzeyinde, 9 (\%4.2) katılımcının beslenme bilgi düzeyinin "orta bilgi" düzeyinde olduğu bulunurken, katılımcıların \%95.3'ünün ise "yetersiz bilgi" düzeyine sahip oldukları rapor edilmiştir. Spor beslenme bilgisi, profesyonel sporcular için oldukça önemlidir, ancak bu çalışmadaki bulgulara benzer olarak katılımcıların "zayıf beslenme bilgisi”ne sahip olduğu sonucuna varılmıştır (Miškulin ve diğ., 2019).

Toplam beslenme bilgisi puanı ve vücut kompozisyonu arasındaki ilişkiyi değerlendiren 66 futbolcunun katıldığı bir başka çalışmada ise; bu çalışmadaki bulgulara benzer olarak sporcuların toplam beslenme bilgisi puanı ile vücut yağ yüzdesi ( $r=-0.041, p=0.036$ ) arasında negatif yönlü bir ilişki olduğu bulunmuştur (Devlin ve diğ., 2017). Sporcular ve antrenörlerin beslenme bilgisi üzerine yapılan 36 çalışmanın sistematik bir incelemesinde, bu çalışmanın sonuçlarını destekler nitelikte; beslenme eğitimi alma durumu ve daha yüksek eğitim düzeyine sahip olmak beslenme bilgisi puanını olumlu etkilemiştir. Ayrıca, ileri yaştaki katılımcıların daha iyi genel beslenme bilgisi düzeyine sahip olduğu sonucuna varılmıştır (Trakman ve diğ., 2016).

Son dönemde spor beslenmesi alanında üzerinde sıklıkla durulan konulardan birisi de sporcuların kafein alım miktarıdır. Kafein, çeşitli mekanizmalar yoluyla fiziksel performansı arttırdığı kanıtlanan hem sporcular hem de sporcu olmayan bireyler tarafindan sıklıkla tercih edilen ergojenik bir destektir. (Pickering ve Kiely, 2019). Egzersiz öncesi 3-6 $\mathrm{mg} / \mathrm{kg}$ VA arasındaki kafein alımı, takım sporcuları için fiziksel performans üzerinde etkili ve güvenli bir ergojenik destek olarak görünmektedir (Chia ve diğ., 2017). Bu çalışmada; futbolcuların içecekler ve besinler yoluyla aldıkları toplam kafein miktarı ortalaması $295.47 \pm 69.73 \mathrm{mg} /$ gün, voleybolcuların ise $347.53 \pm 238.62 \mathrm{mg} /$ gün olarak saptanmıştır. Bu 
Profesyonel Futbol ve Voleybol Oyuncularının Beslenme Durumları, Beslenme Bilgi Düzeyleri, Kafein Alımları ve

Vücut Kompozisyonları Arasındaki İlișkinin Değerlendirilmesi

Evaluation of the Relationship Between Nutritional Status, Nutritional Knowledge, Caffeine Consumption and

Body Composition of Professional Soccer and Volleyball Players

çalışmada her iki grupta bulunan sporcular için alınan ortalama kafein miktarı sağlıklı bir yetişkin için maksimum güvenilir alım düzeyi olarak belirlenen 400 mg/gün'ın altındadır. Futbol ve voleybol gibi dur-kalk aktivitesi olan takım sporlarında $3 \mathrm{mg} / \mathrm{kg}$ VA kafein alımının performansa (dayanıklılık, dur kalk oyunlarında zamanlama, 60 dakikaya kadar yoğun egzersizlere uyum gibi) olumlu etkileri bildirilmiştir (Burke, 2008). Bu çalışmada her iki gruptaki sporcuların da bu miktara yakın düzeyde $(3.97 \pm 1.00 \mathrm{mg} / \mathrm{kg}$ VA, $3.70 \pm 2.37 \mathrm{mg} / \mathrm{kg}$ VA) kafein aldıkları saptanmıştır. Kafeinin, Dünya Dopingle Mücadele Ajansı (WADA) 2004 Yasaklı Listesinden çıkarılmasının ardından, Birleşik Krallık sporcuları arasında bildirilen kafein tüketim miktarı ve kullanım nedenlerini incelemek için yapılan bir çalışmada; atletizm sporcularına (\%32.6) kıyasla bisikletçilerin (\%59.9) performansı arttırmak için daha yüksek oranda kafein tükettikleri bildirilmiştir (Chester ve Wojek, 2008). Bu sporcular günlük olarak \%64.0'ü <200 mg; \%34.8'i 200-400 mg ve \%1.2'si $>400$ mg kafein tükettiklerini (kahve, enerji içeceği, kafeinli ergojenik suplemanlar vs.) bildirmişlerdir. Avustralya'daki 2005 Ironman Triatlon Dünya Şampiyonası'na katılan sporcularla yürütülen bir başka çalışmada sporcuların toplam kafein alım miktarı ortalama $351.0 \pm 281.0 \mathrm{mg} /$ gün ve vücut ağırlığı $(\mathrm{kg})$ başına aldıkları ortalama kafein miktarı ise $4.9 \pm 3.7$ $\mathrm{mg} / \mathrm{kg}$ olarak saptanmıştır (Desbrow ve Leveritt, 2006). Bu çalışmada bu kadar yüksek dozlarda kafein alımı olmamasına karşın önerilen düzeyler arasında olan kafein alımının performansa etkisinin olup olmadığı daha detaylı çalışmalar ile değerlendirilmelidir.

\section{SONUÇ VE ÖNERILER}

Sporcuların beslenme bilgi düzeylerinin yetersiz olması, beslenme alışkanlıklarını ve diyet kalitelerini olumsuz yönde etkileyerek sportif performanslarının azalmasına neden olmaktadır. Literatüre paralel olarak, bu çalışmada SBBÖ'den elde edilen düşük puanlar, profesyonel futbolcular ve voleybolcular arasında endişe verici düzeyde bir beslenme bilgisi yetersizliği olduğunu ortaya koymaktadır. Sonuçlar sporcuların beslenme alanındaki bilgilerini arttırmak ve bu yöndeki alışkanlıklarını olumlu yönde etkilemek, bunla ilişkili olarak sportif performanslarını iyileştirmek için "beslenme eğitimi programları" oluşturulması gerektiğini vurgulamaktadır. Ayrıca mevcut veriler, sporcuların genellikle sportif performansı artırdığı bildirilen kafein alımlarının yüksek düzeyde olduğunu göstermiştir. Literatürde sporcularda kafein alımı üzerine birçok çalışma mevcuttur; ancak sporcular tarafından kafein kullanımı hakkında sınırlı bilgi bulunmaktadır ve takım sporlarında yapılmış çalışmalar halen yetersizdir. Özellikle daha geniş örneklemlerde takım sporcularının beslenme bilgi düzeylerini, beslenme durumlarını ve kafein alımlarını saptamaya yönelik yapılan bilimsel araştırmaların sayısının artırılması gerekmektedir.

Çalışmanın en önemli limitasyonu çalışmaya katılan sporcu sayısının az olmasıdır. Çalışma genelinde popülasyonun artırılması planlanmış ancak mevcut süreç (Covid-19) bu planlamanın uygulanmasına engel olmuştur.

\section{Yazar Katkısı (Author contributions):}

1. Aysu AYHAN: Fikir/Kavram, Tasarım, Veri Toplama ve/veya İşleme, Analiz-Yorum, Makale Yazımı

2. Selen MÜFTÜOĞLU: Fikir/Kavram, Tasarım, Denetleme, Analiz-Yorum, Makale Yazımı, Eleştirel İnceleme

3. Beril KÖSE: Fikir/Kavram, Tasarım, Denetleme, Analiz-Yorum, Makale Yazımı, Eleştirel İnceleme

\section{Etik Kurul İzni ile İlgili Bilgiler}

Kurul Adı: Başkent Üniversitesi Tıp ve Sağlık Bilimleri Araştırma Kurulu

Tarih: 23.10 .2019

Sayı No: KA19/335 


\section{KAYNAKÇA}

1. Baysal, A. (2014). Beslenme. Ankara, Hatiboğlu Yayınevi, 15. Bask1.

2. Baysal, A., Aksoy, M., Besler, T. (2014). Diyet el kitabı. Ankara, Hatipoğlu Yayınları, 8. Bask1.

3. Burke, L.M. (2008). Caffeine and sports performance. Applied Physiology, Nutrition, and Metabolism, 33(6), $1319-34$.

4. Burke, L.M., van Loon, L.J., ve Hawley, J.A. (2016). Postexercise muscle glycogen resynthesis in humans. Journal of Applied Physiology, 122(5), 1055-67.

5. Caldwell, A.R., Tucker, M.A., Butts, C.L., McDermott, B.P., Vingren, J.L., Kunces, L.J., ve diğ. (2017). Effect of caffeine on perceived soreness and functionality following an endurance cycling event. Journal of Strength and Conditioning Research, 31(3), 638-643.

6. Chester, N., ve Wojek, N. (2008). Caffeine consumption amongst British athletes following changes to the 2004 WADA prohibited list. Sports Medicine International Open, 29(6), 524-528.

7. Chia, J.S., Barrett, L.A., Chow, J.Y., ve Burns, S.F. (2017). Effects of caffeine supplementation on performance in ball games. Sports Medicine, 47(12), 2453-2471.

8. Çırak, O., ve Çakıroğlu, F.P. (2019). Sporcu beslenme bilgisi ölçeğinin türkçe formunun geçerlik ve güvenirlik çalışması. Ankara Sağlık Bilimleri Dergisi, 1, 35-49.

9. Desbrow, B., ve Leveritt, M. (2006). Awareness and use of caffeine by athletes competing at the 2005 Ironman Triathlon World Championships. International Journal of Sport Nutrition and Exercise Metabolism, 16(5), 545-558.

10. Desbrow, B., Biddulph, C., Devlin, B., Grand, G.D., Anoopkumar-Dukie, S., ve Leveritt, M.D. (2012). The effects of different doses of caffeine on endurance cycling time trial performance. Journal of Science and Medicine in Sport, 30, 115-120.

11. Devlin, B.L., Leveritt, M.D., Kingsley, M., ve Belski, R. (2017). Dietary intake, body composition, and nutrition knowledge of Australian football and soccer players: Implications for Sports Nutrition Professionals in Practice. International Journal of Sport Nutrition and Exercise Metabolism, 27, 130-138.

12. Duncan, M.J., Eyre, E., Grgic, J., ve Tallis, J. (2019). The effect of acute caffeine ingestion on upper and lower body anaerobic exercise performance. European Journal of Sports \& Exercise Science, 19(10), 1359-1366.

13. FAO. (2001). Human energy requirements, Food and nutrition technical report, Rome: report of a joint FAO/WHO/UNU expert consultation.

14. Fink, H.H., Burgoon, L.A., ve Mikesky A.E. (2006). Practical Applications in Sports Nutrition. Canada: Jones and Bartlett Publishers.

15. Goldstein, E.R., Ziegenfuss, T., Kalman, D., Kreider, R., Campbell, B., Wilborn, C., ve diğ. (2010). International society of sports nutrition position stand: Caffeine and performance. Journal of the International Society of Sports Nutrition, 7, 5.

16. Heaney, S., O'Connor, H., Michael, S., Gifford, J., ve Naughton, G. (2011). Nutrition knowledge in athletes: a systematic review . International Journal of Sport Nutrition and Exercise Metabolism, 21(3), 248-261.

17. IOM (Institue of Medicine). (2005). Dietary references intakes for energy, carbonhydrate, fiber, fat, fatty acids, cholesterol, protein and amino acids. Washington DC, National Academies Press.

18. Jenner, S.L., Trakman, G., Coutts, A., Kempton, T., Ryan, S., Forsyth, A., ve diğ. (2018). Dietary intake of professional Australian football athletes surrounding body composition assessment. Journal of the International Society of Sports Nutrition, $15,43$.

19. Jeukendrup, A.E. (2017). Periodized nutrition for athletes. Sports Medicine, 47(Suppl 1), 51-63.

20. Kreider, R.B., Wilborn, C.D., Taylor, L., Campbell, B., Almada, A.L., Collins, R., ve diğ. (2010). ISSN exercise \& sport nutrition review: Research \& recommendations. Journal of the International Society of Sports Nutrition, 7, 7.

21. Kerksick, C.M., Wilborn, C.D., Roberts, M.D., Smith-Ryan, A., Kleiner, S.M., Jäger, R., ve diğ. (2018). ISSN exercise \& sports nutrition review update: Research \& recommendations. Journal of the International Society of Sports Nutrition, 15, 38.

22. Lohman, R., Carr, A., ve Condo, D. (2019). Nutritional intake in Australian Football Players: sports nutrition knowledge and macronutrient and micronutrient intake. International Journal of Sport Nutrition and Exercise Metabolism, 29(3), 289-296.

23. Mastaloudis, A., Driskell, J., ve Wolinsky, I. (2006). Sports nutrition: Vitamins and trace elements. New York: CRC/Taylor and Francis, p. 183-200.

24. Miškulin, I., Šašvari, A., Dumić, A., Bilić-Kirin, V., Špiranović, Ž., Pavlović, N., ve diğ. (2019). The general nutrition knowledge of professional athletes. Food in Health and Disease, scientific-professional journal of nutrition and dietetics, 8(1), 25-32.

25. Otman, Ö.T. (2017). Adolesan futbolcuların beslenme durumları ile sıvı tüketimleri ve kafein alımlarının değerlendirilmesi. Sağlık Bilimleri Enstitüsü Diyetetik Programı Yüksek Lisans Tezi, Hacettepe Üniversitesi.

26. Özdemir, G. (2010). Spor dallarına göre beslenme. Spormetre Beden Eğitimi ve Spor Bilimleri Dergisi, 8, 1-6.

27. Papadopoulou, S.D., Papadopoulou, S.K., Vamvakoudis, E., ve Tsitskaris, G. (2008). Comparison of nutritional intake between volleyball and basketball women athletes of the olympic national teams. Gazzetta Medica Italiana Archivio per le Scienze Mediche, 167(4), 147-52. 
Profesyonel Futbol ve Voleybol Oyuncularının Beslenme Durumları, Beslenme Bilgi Düzeyleri, Kafein Alımları ve

Vücut Kompozisyonları Arasındaki İlişkinin Değerlendirilmesi

Evaluation of the Relationship Between Nutritional Status, Nutritional Knowledge, Caffeine Consumption and

Body Composition of Professional Soccer and Volleyball Players

28. Pickering, C., ve Kiely, J. (2019). What should we do about habitual caffeine use in athletes? Sports Medicine, 49 (6), $833-842$.

29. Potgieter, S., Wright, H.H., ve Smith, C. (2018). Caffeine improves triathlon performance: A field study in males and females. International Journal of Sport Nutrition and Exercise Metabolism, 28, 228-237.

30. Ranchordas, M.K., King, G., Russell, M., Lynn, A., ve Russell, M. (2018). Effects of caffeinated gum on a battery of soccer-specific tests in trained university-standard male soccer players. International Journal of Sport Nutrition and Exercise Metabolism, 28(6), 629-634.

31. Rodriguez, N.R., DiMarco, N.M., ve Langley S. (2009). Position of the American Dietetic Association, Dietitians of Canada, and the American College of Sports Medicine: Nutrition and athletic performance. Journal of the American Dietetic Association, 109(3), 509-27.

32. SB (Sağlık Bakanlığı). (2016). Türkiye Beslenme Rehberi 2015 TÜBER. Ankara, Yayın No: 1031.

33. Southward, K., Rutherfurd-Markwick, K.J., ve Ali, A. (2018). The effect of acute caffeine ingestion on endurance performance: a systematic review and meta-analysis. Sports Medicine, 48, 1913-1928.

34. Spendlove, J.K., Heaney, S.E., Gifford, J.A., Prvan, T., Denyer, G.S., ve O'Connor, H.T. (2012). Evaluation of general nutrition knowledge in elite Australian athletes. British Journal of Nutrition, 107, 1871-1880.

35. Spronk, I., Heaney, S.E., Prvan, T., ve O’Connor, H.T. (2015). Relationship between general nutrition knowledge and dietary quality in elite athletes. International Journal of Sport Nutrition and Exercise Metabolism, 25, 243-251.

36. Stojanović, E., Stojiljković, N., Scanlan, A.T., Dalbo, V.J., Stanković,. R, Antić, V., ve diğ. (2019). Acute caffeine supplementation promotes small to moderate improvements in performance tests indicative of in-game success in professional female basketball players. Applied Physiology, Nutrition, and Metabolism, 44 (8), 849-856.

37. Tallis, J., Duncani M.J., ve James, R.S. (2015). What can isolated skeletal muscle experiments tell us about the effects of caffeine on exercise performance. British Journal of Pharmacology, 172, 3703-3713.

38. Thomas, D.T., Erdman, K.A., ve Burke, L.M. (2016). American College of Sports Medicine joint position statement. Nutrition and athletic performance. Medicine \& Science in Sports \& Exercise, 48, 543-68.

39. Trakman, G.L., Forsyth, A., Devlin, B.L., ve Belski, R. (2016). A systematic review of athletes' and coaches' nutrition knowledge and reflections on the quality of current nutrition knowledge measures. Nutrients, 8(9), 570.

40. Williams, C., Rollo, I. (2015). Carbohydrate nutrition and team sport performance. Sports Medicine, 45, 1(1), 13-22.

41. Zorba, E. (1989). Milli Takım Düzeyindeki Türk Güreşçileri için Derialtı Yağ Kalınlığı Denklemi Geliştirilmesi. Doktora Tezi. Marmara Üniversitesi. 